\title{
A Study in Frustration: Analysis of Human Remains Removed from the Coker Mound Site (41CS1)
}

Sharon McCormick Derrick Unknown

Follow this and additional works at: https://scholarworks.sfasu.edu/ita

Part of the American Material Culture Commons, Archaeological Anthropology Commons, Environmental Studies Commons, Other American Studies Commons, Other Arts and Humanities Commons, Other History of Art, Architecture, and Archaeology Commons, and the United States History Commons

Tell us how this article helped you.

This Article is brought to you for free and open access by the Center for Regional Heritage Research at SFA ScholarWorks. It has been accepted for inclusion in Index of Texas Archaeology: Open Access Gray Literature from the Lone Star State by an authorized editor of SFA ScholarWorks. For more information, please contact cdsscholarworks@sfasu.edu. 


\section{A Study in Frustration: Analysis of Human Remains Removed from the Coker Mound Site (41CS1) \\ Creative Commons License \\ (c) (1) (9)}

This work is licensed under a Creative Commons Attribution-NonCommercial 4.0 International License 


\section{A STUDY IN FRUSTRATION: ANALYSIS OF HUMAN REMAINS REMOVED FROM THE COKER MOUND SITE (41CS1)}

\section{Sharon McCormick Derrick}

\section{Introduction}

Human skeletal remains were removed from the Coker Mound site (41CS1) by unidentified excavators sometime immediately prior to the Texas Archeological Society (TAS) meetings of 1995. Mike Turner, a Steward in the Office of the State Archeologists' Texas Archeological Steward Network and a founding member of the Friends of Northeast Texas Archaeology, was able to retrieve a cranium, mandible, and six cervical vertebrae from this collection for a brief period, bringing them to the TAS meetings. It was his dedication that provided the opportunity for these remains to be studied.

\section{Description of the Remains}

The cranium (Figure 1), mandible (Figure 2), and vertebrae were reportedly found in one layer of a three-layered burial deposit in an earthen mound. These elements appeared to belong to the same individual based on dental occlusion, bone size and morphology, matching vertebral and occipital articulation facets, and general color and appearance of the elements.

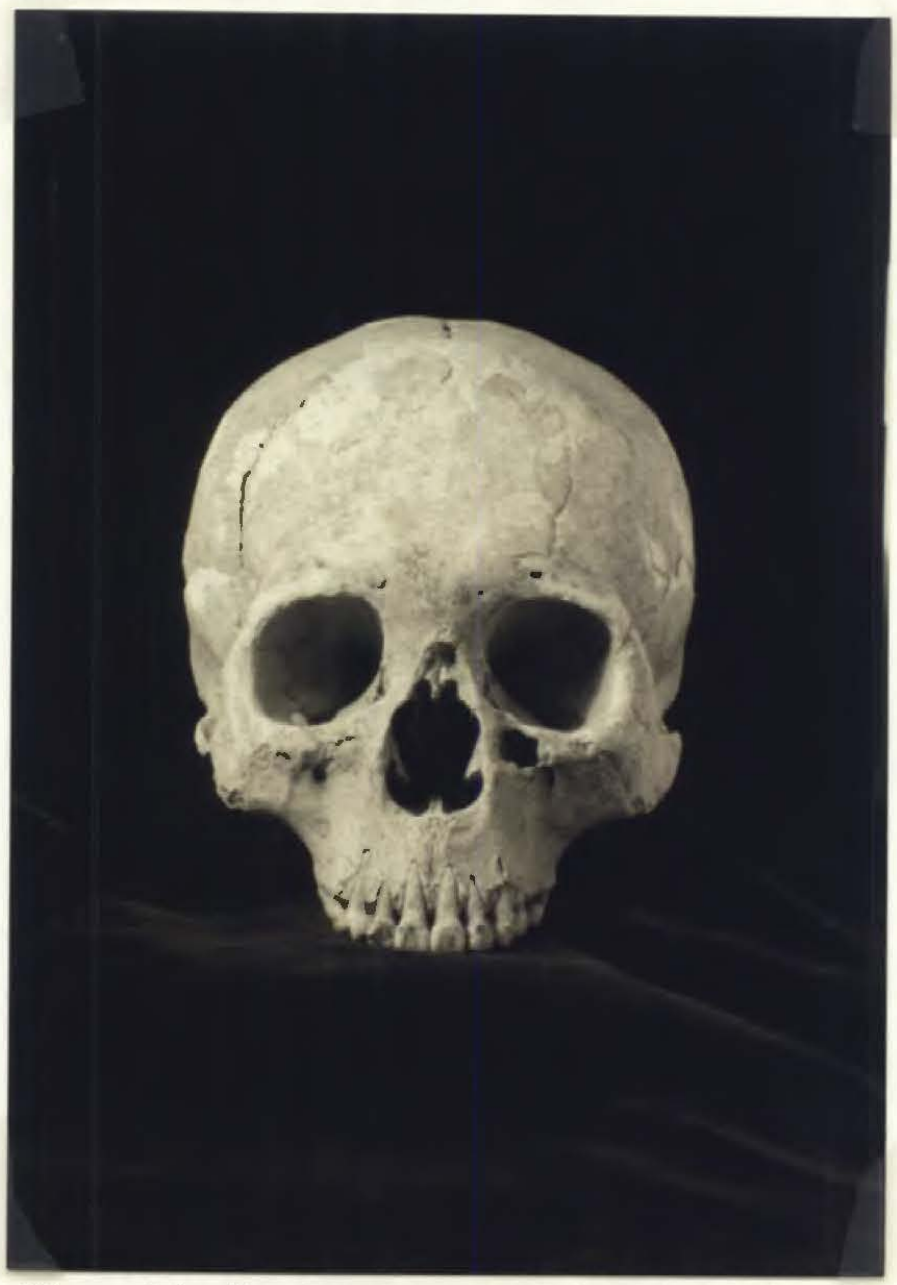

Figure 1. Anterior View of the Cranium from the Coker Mound (41CS1). 


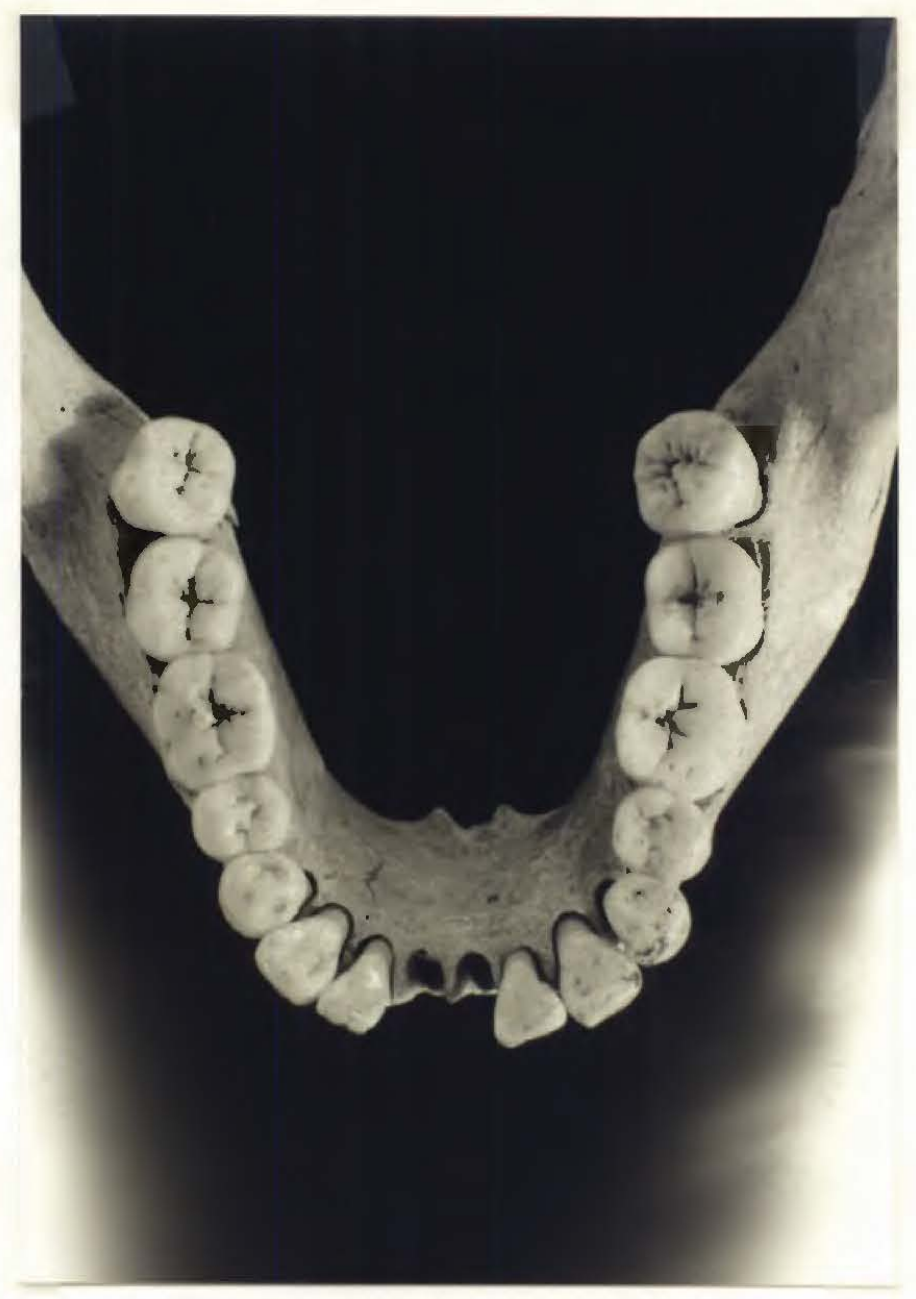

Figure 2. Mandibular Dentition from Coker Mound (41CS1).

With the exception of one vertebra, all of the elements were in an excellent state of preservation, marred only by superficial flaking of the exterior surfaces of the superior cranial vault, and minor breakage of the delicate facial bones. The cranium and mandible were virtually complete, with all but the most fragile of the cranial bones present and in articulation. Fifteen occluded adult teeth were present in the maxillae. The mandible contained only 14 of 16 occluded permanent teeth because the two central incisors were lost by the excavators after the mandible was removed from the burial (Mike Turner, personal communication). Five vertebrae from the neck were also present for evaluation: the atlas, axis, cervical vertebrae numbers three and four, and one fragmented cervical vertebra that could have been either number five or number six. One additional vertebra was retained for isotopic analysis, yielding a 1 sigma calibrated date of A.D. 1300 C 1435 for this individual (Perttula et al. 1997, this volume).

The cranium was modeled (shaped permanently into a desired form when the individual was a child) in the tabular parallelo-fronto-occipital style (Figure 3). Tabular parallelo-fronto-occipital modeling was practiced by Northeast Texas Caddoan peoples between ca. A.D. 1000-1700 (Derrick and Wilson 1997). This style of modeling, in which the front and back of the head were flattened in a complementary fashion, was likely achieved by a sliding board mechanism (Figure 4 ). 


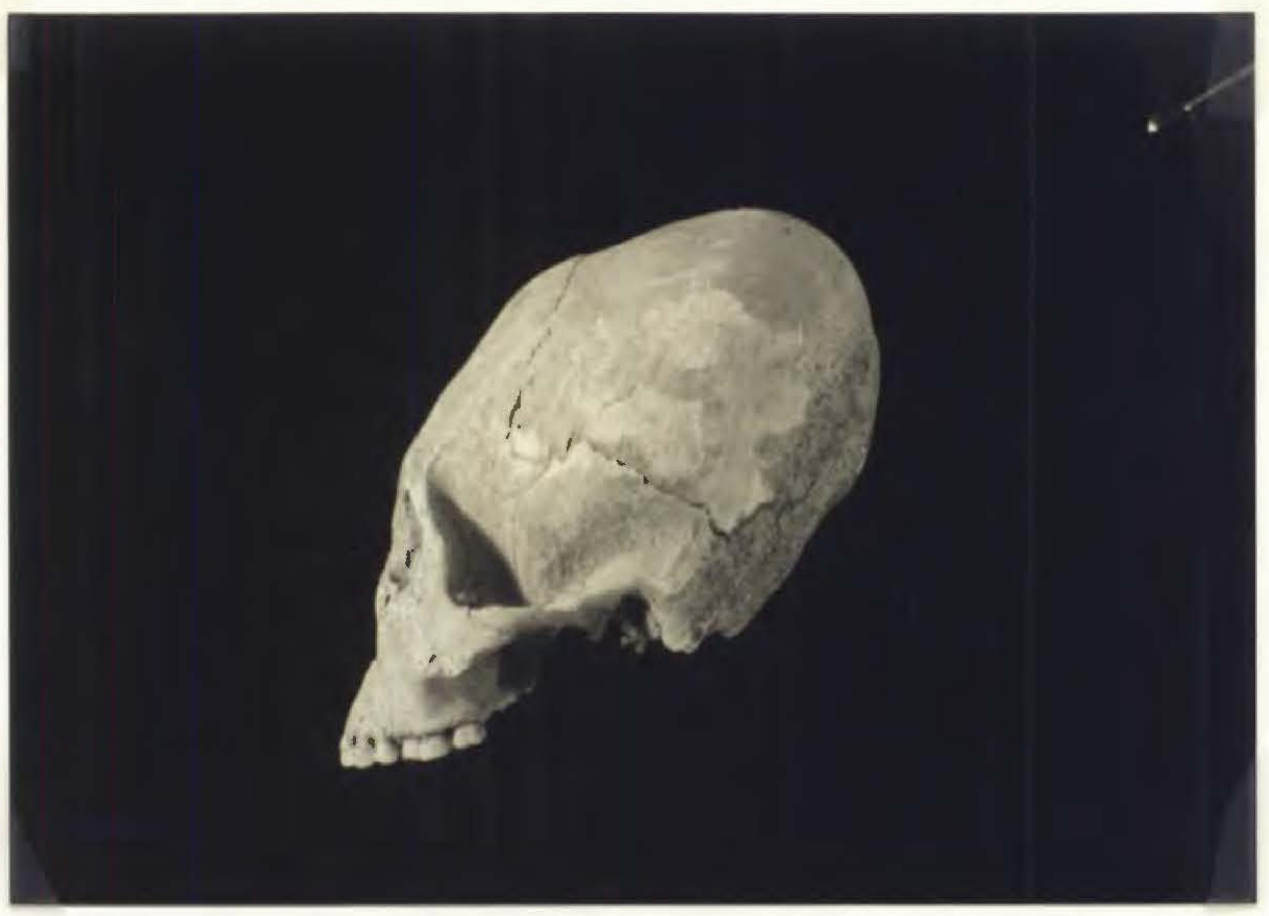

Figure 3. Lateral View of the Cranium from the Coker Mound site. Note the pronounced tabular parallelo-fronto-occipital modeling.

The resulting shape was similar in appearance to some forms of annular modeling (produced by wrapping the head), but the view of the top of the cranium revealed a characteristic lateral expansion of the parietal eminences (Figure 5). This expansion at the top and sides of the head was evidence that boards were probably used in the modeling process.

The presence of multiple sutural ossicles (extra small bones located within the cranial suture lines) is a common developmental anomaly. Although these ossicles do occur in naturally shaped skulls, cranial modeling is one factor that has been linked to their development, especially those ossicles known as Wormian bones that occur in the lambdoidal suture (El-Najjar and Dawson 1977; Gottlieb 1978). A number of these ossicles were observed in the lambdoidal suture on the posterior surface of the Coker cranium (Figure 6).

\section{Sex Estimation}

The individual was probably a female, based on metric and non-metric cranio-facial sex criteria, and the size and gracility of the elements. The vault was smooth, lacking pronounced muscular attachment ridges. The mastoid processes at the base of the cranium were small, and the zygomatic arch processes smoothed out at the anterior margins of the auditory meati (ear openings). Each eye orbit was relatively round, containing a sharp supra-orbital margin, but lacking a pronounced supra-orbital ridge. Glabellar projection was minimal. The measurements of the palate were relatively small, and finally, the chin was rounded and exhibited a small mental eminence. All of these characteristics are typically considered to represent female skeletal traits (Bass 1971; Steele and Bramblett 1988). However, even though the skull usually exhibits strong sex characters, any conclusions based on one area of the body are somewhat suspect (Bass 1971; Steele and Bramblett 1988). 


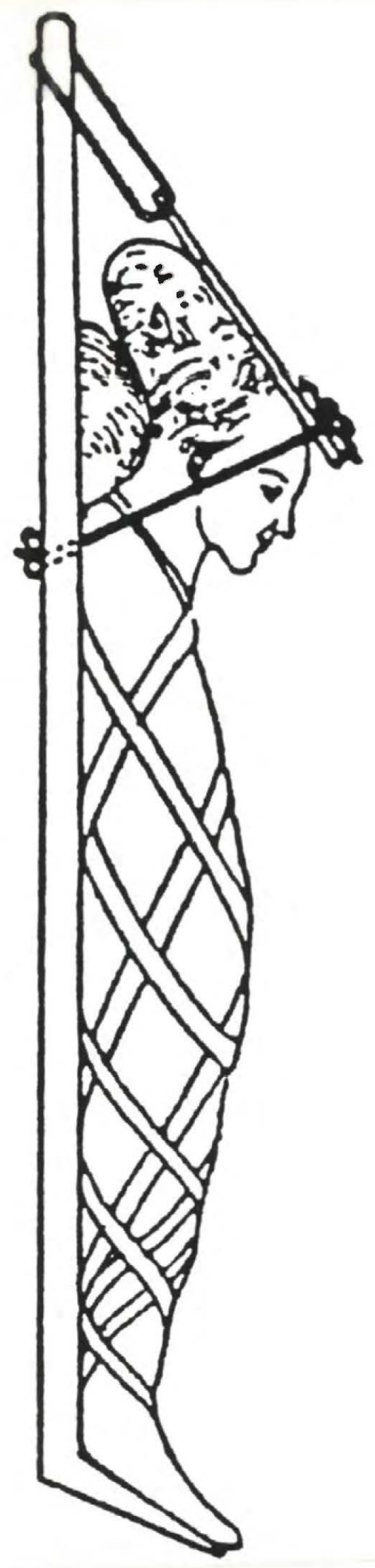

Figure 4. Illustration of Tabular Parallelo-Fronto-Occipital Modeling as Produced on a Cradleboard (after Dembo and Imbelloni 1938:294). 


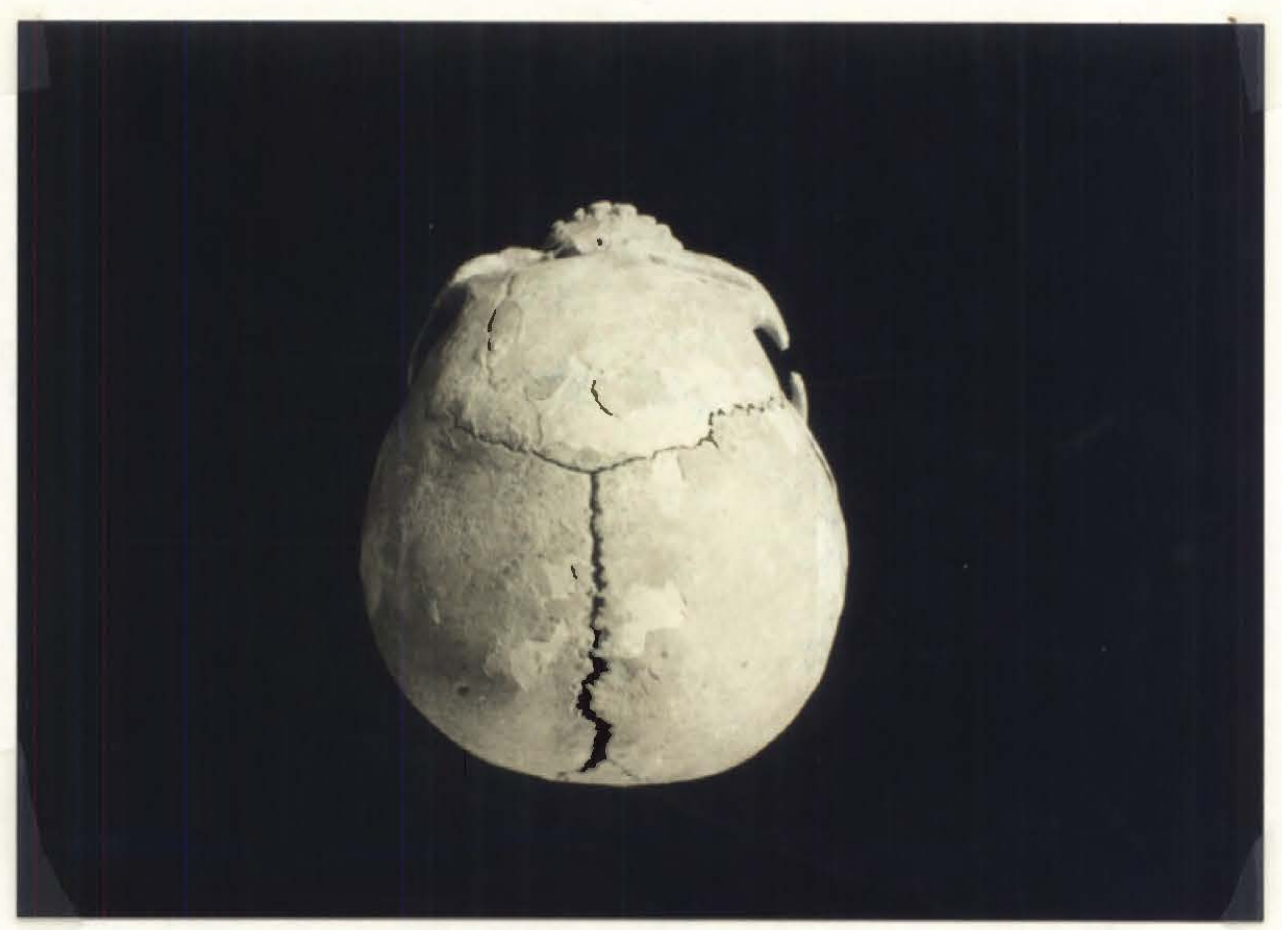

Figure 5. Superior View of the Parietal Eminences of the Cranium from the Coker Mound site.

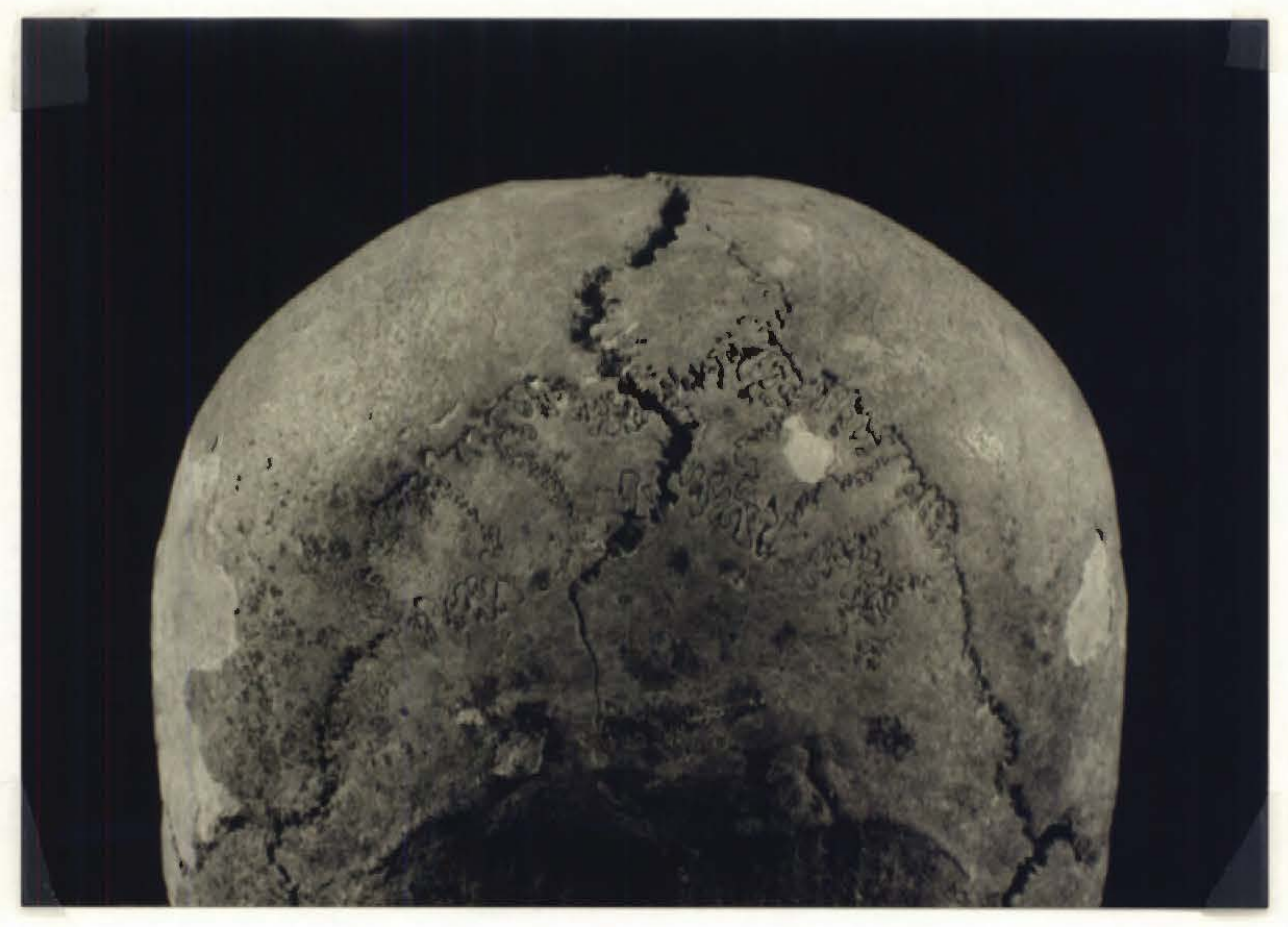

Figure 6. Sutural Ossicles (Wormian Bones) Occurring in the Lambdoidal Suture of the Coker Cranium. 


\section{Age Estimation}

Age at death was estimated at 18-22 years. This was based on the completed eruption and occlusion of the third molars, dental wear scores, lack of fusion at the sphenooccipital articulation (basilar suture), and the degree of closure of other cranial sutures.

Three third molars were present and exhibited minimal wear. Occlusion of the third molars is an indication that the individual was probably at least 18 years old at death (Bass 1971; Steele and Bramblett 1988). Overall dental wear was scored using Scott's (1979) method for the anterior teeth and Smith's (1984) method for the molars. Wear on the teeth was light to moderate, with a mean score of 2.1 out of eight possible points for the anterior teeth, and a mean of 13.9 out of 40 possible points for the molars, excluding the recently occluded third molars. Such minimal wear found on Native American teeth of the age of the Coker Mound site is typically associated with younger individuals (cf. Scott 1979; Smith 1984).

Cranial suture closure was assessed by recording the degree of closure for 18 suture segments according to stages developed from the work of Meindl and Lovejoy (1985) and reproduced in the Texas A\&M University Physical Anthropology Laboratory Data Form (Colby et al. n.d.). Of the 18 segments, four were open, eight exhibited minimal closure, six exhibited significant closure, and none of the sutural segments were completely fused. The sutural segment between the sphenoid and occipital bones, which typically fuses between the ages of 17 and 22 years, is an important indicator of physical maturity, and this segment exhibited only minimal closure (Steele and Bramblett 1988). The degree of suture closure observed on this cranium was characteristic of a young adult under the age of 22 (Steele and Bramblett 1988; Colby et al. n.d.).

\section{Dentition}

All but one of the individual's upper adult teeth (the left third molar) were present, articulated in the maxillae, and appeared to be free of caries (Figure 7). The alveolus at the location of the missing tooth exhibited a small round aperture, and the alveolar surface had a rippled, slightly infectious appearance. This third molar may not have erupted, instead remaining in the alveolus, or it may have developed as a small peg tooth that was lost perimortem or postmortem. Other items of particular note included the double shoveling trait on the incisors and the atypical orientation of the upper premolars. Both of the right premolars were rotated slightly toward each other, one distally and one medially. The left medial premolar was rotated slightly in the direction of the distal premolar and the left distal premolar was rotated almost 360 degrees.

The mandible contained 14 adult teeth, having lost the two central incisors postmortem (see Figure 2). Three small caries were observed in the mandibular dentition. The right first molar contained a small caries in the buccal groove of the crown and another small caries in the pit on the central occlusal surface of the crown. The right second molar also contained a small caries in the pit on the central occlusal surface.

\section{Paleopathology}

The only evidence of any pathological condition other than the dental caries was found in a slight alveolar porosity located on the buccal surfaces of the maxillae in the general area of the right and left upper premolars, and also in the area of the missing upper left third molar. The presence of this porosity indicated that the individual might have suffered from gum infection around the upper teeth. 


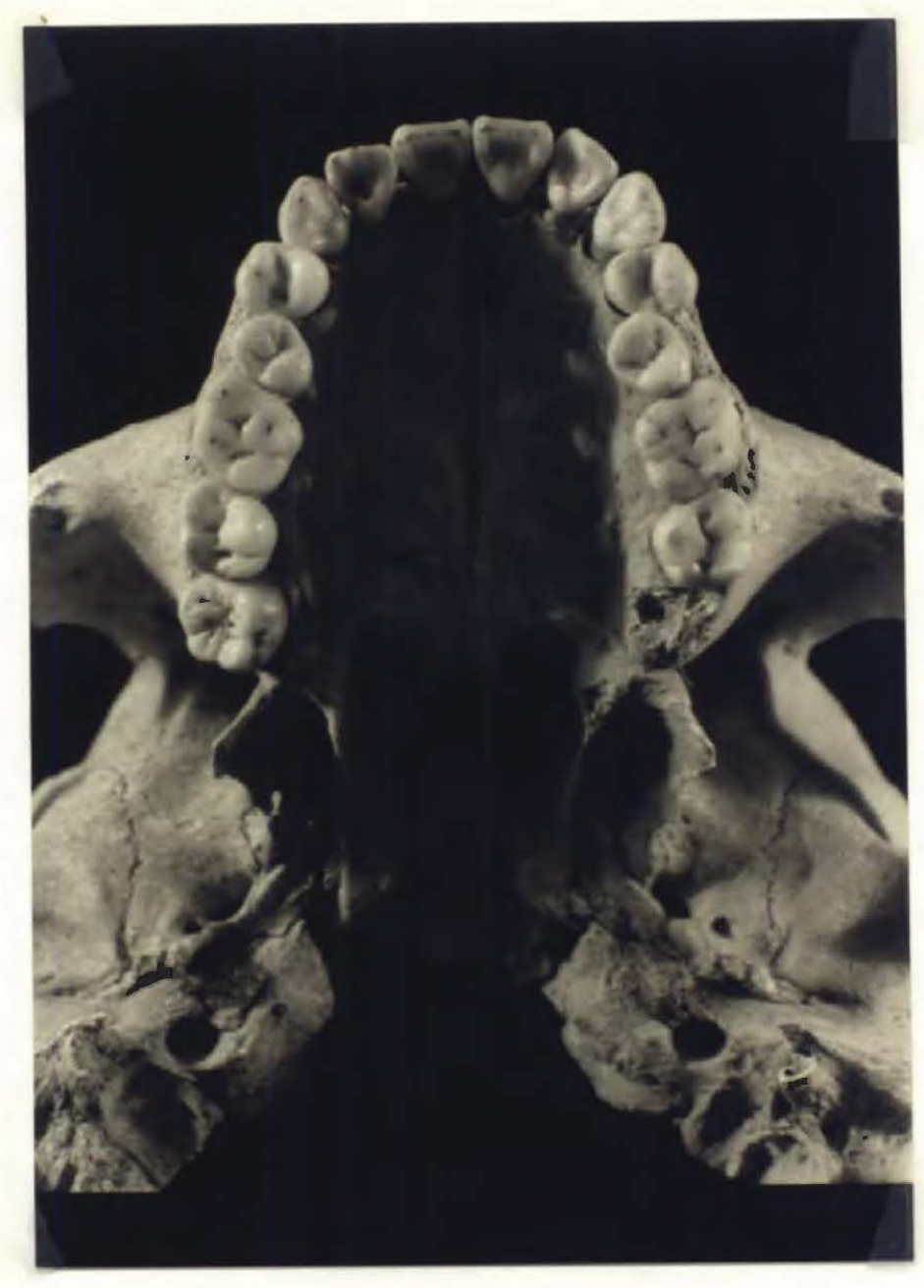

Figure 7. Maxillary Dentition. Note the rotated premolars and the absence of the left third molar.

\section{Summary}

The cranium, mandible, and vertebrae removed from the Coker Mound site, and later examined by the author, probably belonged to one individual, a young Caddoan adult female aged 18-22 years at death. This is supported by the archeological evidence retrieved from within the mound, including the recovery of Caddoan ceramic sherds and other artifacts typically associated with Caddoan groups from Northeast Texas (Perttula et al., this volume). In addition, the cranium was modeled, a form of body ornamentation practiced by Caddoan peoples, but not commonly practiced by neighboring non-Caddoan peoples (Derrick and Wilson 1997). The calibrated radiocarbon date of A.D. 1300-1435 acquired through isotopic analysis of one of the cervical vertebrae, combined with the recovery of an engraved bottle similar to the Haley Engraved type, also indicates that this individual probably lived sometime during the Middle Caddoan Period (Perttula et al., this volume). Based on the condition of the skeletal remains, this person was probably in relatively good health previous to some unknown acute affliction, accident, or violent act that precipitated death. 


\section{Return of the Remains}

The reference to frustration in the title of this article alludes to the feelings of dismay and impotence the author experienced during the course of this analysis. The removal of these remains from the Coker Mound represents several forms of loss. First and most tragic is the vandalism and desecration perpetrated upon this person when someone removed portions of the body and treated them as trophies. Secondly, the Coker Mound site is potentially an important source of information about the Caddoan heritage in Northeast Texas, and yet we have little concrete data from this site. Due to the recent digging of unknown individuals, much of this evidence has been destroyed. If these remains were a part of a three-layered burial deposit, a great deal of data has been lost. Certainly we can never know more about this individual's biological history than what has been gleaned from these few remains. Unfortunately, the end to the story is as frustrating as the beginning. The remains have been returned to the collection from whence they came.

\section{References Cited}

Bass, W. M.

1971 Human Osteology: A Laboratory and Field Manual of the Human Skeleton. Missouri Archaeological Society, Columbia.

Colby, G. R., B. W. Baker, D. L. Carlson, H. Danzeiser Dockall, P. M. Landau, S. K. McCormick, B. W. Olive, J. F. Powell, B. S. Shaffer, and D. G. Steele

n.d. Texas A\&M University Physical Anthropology Laboratory Data Form. Texas A\&M University, College Station.

Dembo, A. and J. Imbelloni

1938 Deformaciones: Intencionales del Cuerpo Humano de Caracter Etnico. Jose Anesi, Buenos Aires.

Derrick, S. M. and D. E. Wilson

1997 Cranial Modeling as an Ethnic Marker Among the Prehistoric Caddo. Bulletin of the Texas Archeological Society 68, in press.

El-Najjar, N. Y. and G. Dawson

1977 The Effect of Artificial Cranial Deformation on the Incidence of Wormian Bones in the Lamboidal Suture. American Journal of Physical Anthropology 46:155-160.

Gottlieb, K.

1978 Artificial Cranial Deformation and Increased Complexity of the Lamboid Suture. American Journal of Physical Anthropology 48:213-214.

Meindl, R. S. and C. O. Lovejoy

1985 Ectocranial Suture Closure: A Revised Method for the Determination of Skeletal Age at Death Based on the Lateral-Anterior Sutures. American Journal of Physical Anthropology 68:57-66.

Perttula, T. K., M. Turner, and B. Nelson

1997 A Radiocarbon Date from the Coker Mound (4ICS1). Journal of Northeast Texas Archaeology 9:17-20. 
Scott, E. C.

1979 Dental Wear Scoring Technique. American Journal of Physical Anthropology 51:213-218.

Smith, B.

1984 Patterns of Molar Wear in Hunter-Gatherers and Agriculturists. American Journal of Physical Anthropology 63:39-56.

Steele, D. G. and C. A. Bramblett

1988 The Anatomy and Biology of the Human Skeleton. Texas A\&M University Press, College Station. 